\title{
Correction of the claim for microfinance market of 1.5 billion clients
}

\author{
Tomáš Hes ${ }^{1, *}$, Anna Poledňáková ${ }^{2, \star *}$ \\ ${ }^{1}$ Institute of Tropics and Subtropics, Czech Agricultural University Prague, \\ Kamýcká 129, 165 21, Prague 6, Czech Republic \\ Tel.: +420 77707160 \\ ${ }^{2}$ Faculty of International Relations, University of Economics in Prague, \\ Nám. W. Churchilla 4, 130 67, Prague 3, Czech Republic \\ Tel.: +420605545047 \\ *,**E-mail address: thes@myelen.com , apolednakova@myelen.com
}

\begin{abstract}
Since the beginnings of modern microfinance in the $70 \mathrm{~s}$, the industry continued to grow rapidly, albeit fueled by dubious assumptions related to market potential. Boosted by Nobel Prize award, thousands of new MFIs are currently being created in the lure of market potential, estimated at one and half billion of unattended clients. The estimates, however, differ drastically and there is no wide scale assessment available deducing the unattainable market strata, detrimental to sustainable microfinance, from the inflated estimates. The exaggerations are to be denoted as unrealistic and excluded from the global estimates. This study intends to quantify the market wrongly assumed to form part of the microfinance market and to deduce the real size of the potential global microfinance sector, appraising the size of the market that should not be counted into the integral demand, since it is unsustainable or harmful to the players involved.
\end{abstract}

Keywords: microfinance; funding; sustainable; demand; market assessment

\section{INTRODUCTION}

So far no general consensus exists on how big is the potential microfinance market. Many authors point out that microfinance, defined as financial services that is provided to unemployed or low-income individuals or groups without access to these, is not for everyone and may be inappropriate especially where certain pre-conditions are absent. However, most market estimates uncritically count with a great part or all the "unbanked" adults in developing countries as potential microfinance customers and arrive at undue market estimates. Evidence raises a concern that demand may often be overestimated by a considerable margin (Anand and Rosenberg, CGAP, 2008). Lack of sober evaluations of the real size of the market may have detrimental impact on the clientele as microfinance providers, motivated by unrealistic expectations, are fuelling more capital into the sector than necessary. 
Flaming proclamations of private and governmental microfinance programs advocating the global importance of microfinance should sober down and restrict their focus only on those poor able to initiate activities with growth potential, forming real, attainable and sustainable markets (Parker and Pearce, CGAP, 2002). As shown in this study, the realisticsize of the global microfinance market may be of a smaller size than the numbers often cited in publications and repeated in conferences. The reasons why only reduced part of the population should be considered target market, are varied. The study has focused on loan and savings, although microfinance encompasses other products. Credit and savings however stay the core of microfinance services, being the key components, while other products such as microinsurance protecting the borrowers liabilities, serve complementary functions. In the long run, sustainable MFIs center their activity around savers and borrowers.

Only a fraction of the population is interested in savings or can qualify for microfinance services. According to CGAP, for microcredit to be appropriate, a pre-existing level of ongoing economic activity is needed (Ibid.). Morduch and Haley (2002) acknowledge the entrepreneurial skills as crucial as not all people are equally able to take on debt. Versluysen (1999) states that, the aged and totally indigent should not belong to microfinance programs, because they would not be able to use the loan productively, and would be burdened with debt. According to the World Bank (2011), chronically poor, refugees and destitute people without regular income, should be rather provided with other forms of assistance than microfinance, such as access to food and clean water, housing, and incomegenerating activities. The sick and mentally ill are also not good candidates for microfinancial services, as it is recognized that affected are less able to benefit from credit over time. Populations living in cultures that forbid conventional interest rate or in totalitarian regimes not permitting free market practices hardly belong to potential microfinance market.

Considering all obstacles in successful provision of microfinance services to the poor, the potential microfinance market is likely to be smaller than estimated in shallow, frequently repeating market guesses. The aim of this paper is thus to briefly examine and quantify different market segments excluded from the real demand and on the basis of available FAI statistics of number of adults without access to financial services try to define how big is the microfinance market wrongly considered as part of the global demand, concluding the real size of world's microfinance market.

\section{CURRENT ESTIMATES OF THE GLOBAL MICROFINANCE MARKET}

As there are many definitions of microfinance, the authors employ a definition used by MixMarket (2010), defining microfinance services as retail financial services that are relatively small in relation to the income of a typical individual, overlapping with another definition, identifying microfinance as credit, savings and other essential financial services within the reach of millions of people who are too poor to be served by regular banks, because they are unable to offer sufficient collateral (van Maanen, Oikocredit, 2004). The authors believe these definitions correspond to the general understanding of the concept of microfinance used by the mentioned sources, yet also should be complemented with the notion of sustainability, as long term microfinance operations cannot function on unsustainable basis.

The popular yet deceptive estimates of the size of the microfinance market potential, highlighted by this study as misguided, differ across the whole spectrum of players and reach 
up to almost a half of the total number of adults in developing countries, which is estimated at 3.75 billion (Kendall et al., World Bank, 2010), provided the MFIs do not accept under aged as clients.

Bernhardt estimates the total market for microfinance at unattended 1.5 billion people (GC Capitalideas, 2009). The same number of 1.5 billion people was quoted by McKinsey \& Company during the Microfinance Investor Roundtable in Washington DC in 2006 (Swibel, Forbes, 2008). Swanson estimates the total market potential of 1.5 billion clients (DW Markets, 2007). Lyman et al. (CGAP and IFC, 2011) estimate the number of potential microfinance clients at 2.7 billion adults worldwide, regarding also all those who do not have a savings or credit account in their name with a bank or other formal institution as potential clients. International association of microfinance investors estimate that an additional US\$270 billion is needed to provide financial services to the world's 1.5 billion working poor (Trant, IAMFI, 2010). According to PlanetFinance estimates over 500 million entrepreneurs remain excluded from financial services.(Planet Finance, 2010) 1.8 billion of people experienced unmet demand for credit services (Robinson, 2001), while 2.5 billion people do not use financial services at all (Chaia et al, 2009).

Seen from the point of view of the volume of capital needed, which seem to be centered around USD $300 \mathrm{bn}$. Swanson estimates the total commercial market of more than US\$250 billion. (DW Markets, 2007) Unmet demand was estimated by Unitus in 2006 at $90 \%$ of eligible self-employed lacking access to microfinance programs, reaching US\$ 720 million USD. Blue Orchard estimated in 2004 that there were 500 million households requiring access to micro-financial services, arriving at a worldwide demand of US\$ 100 billion (Brugger and Duggal, 2004). Microcapital estimated $4 \%$ of the overall global demand for microfinance services is being met, valuing the potential global microfinance market to be worth US\$ 300 billion, which brings the total number of clients when using the average microloan size. Research department of Deutsche Bank in 2007 considered the funding gap of around USD $250 \mathrm{bn}$. PH\&N Investment service equally considered microfinance institutions' financial needs estimated to be US\$ 300 billion across all funding sources in 2013.

The average loan size differs importantly due to provision source, region as well as estimates and moreover, does not have a representative value for the total estimate of microfinance clientele, due to lack of vinculation with savings services as well as a sufficient lack of clarity due insufficient information base on the average microloan size. Microfinance NGO credits are approximately less than a quarter the size of the average loan provided by a microfinance bank (Cull, Demirgüç-Kunt and Morduch, 2009a). Moreover, NGOs more often operate in rural areas and use group lending rather than individual types of contracts with an average loan size of USD 315. (DB Research, 2013) Furthermore, MFIs often advertize average loan size as an important indicator pertaining outreach, and as a reinforcing signal for their main mission. (Armendáriz, 2009) Also, the average size of a microfinance loan was $\$$ 522.8 globally in 2010, according to MIX Market data, whereas the average loan size in India is only about a fourth of that at $\$ 144$. (Crisil, 2010) Mix Market, the frequent source of the estimates, however reunites data of greater, more formalized MFIs, interested and capable of international presentation, leaving a wide spectrum of especially rural institutions or local institutions uninterested in Mix Market participation.

There are many of other financial institutions and intermediaries that include some significant proportion of poor and low-income people among their clientele, including government agricultural and development banks, postal and other savings banks, savings and loan cooperatives, and rural banks and that go on uncaptured (Rosenberg CGAP, 2008). The 
database captures only a small fraction of these other institutions and morever, the Mix market database contains relatively little information about the savings services of the participating institutions.

If we use the average microloan size of 522 USD in 2010, we arrive at the number of 574 millions of microcredit clients.

Concluding, the market estimates vary significantly between 300 million and 2,700 million clients. Frequently is cited the potential market estimate of 1.5 billion people, which we take as the benchmark under review of this study, due to its frequency in mainstream literature as well as affinity to the average market estimate cited.The study considers the sum to be misleading and postulates the need to reduce it to more realistic statement.

\section{SIZE AND STRUCTURE OF THE GLOBAL MICROFINANCE ANTIMARKET}

To be able to assess the approximate size of the unattainable market we focus on quantifiable market segments that cannot be served sustainably by MFIs, on population that is unable to service debt or that can be hurt by microfinance mechanics. These markets should not be counted into potential market estimates. The authors use therefore the concept of "Microfinance Antimarket" as a space unsuited for microfinance, yet wrongly included in the current estimates. The Microfinance Antimarket is formed by two types of clientele: clients of type A who are found in any market disregarding its geographic location and clients of type $\mathrm{B}$, living in specific regions.

Microfinance services without microcredit as their natural element are incomplete from the point of view of sustainability. The Antimarket A clients are thus considered persons unsuited for debt in form of microcredit, such as people too poor, ill or disabled who are incapable to use loans osustainably in the long term lacking the steady repayment income flow or people who simply don't want microloans, lack creditworthiness or are incapable of periodic saving. The available microfinance delivery systems can't thus lend to them without incurring unsustainable default levels. Also, many clients who qualify for loans are not necessarily borrowing all the time. To Antimarket B clients belong those living in regions stricken by wars and conflicts, cultures that are clearly unsuitable for microfinance provision, markets with predominant religious practices that do not permit use of classic style of microfinance.

\section{1. Clientele that cannot qualify}

Not all of the potential microfinance clients qualify for savings or for a loan. The biggest excluded group inapt for loan mechanics, consists of people who do not have an income large or reliable enough to meet a loan's payments. The very poor can be described as heterogeneous group of people experiencing deprivations, in particular being displaced people, migrant, ethnic or indigenous minorities, and usually living in remote areas or difficult environments with seasonally flooded or eroded areas (Hulme et al., 2007).

In the study from Indonesia, focused on microfinance provided to extremely poor, $40 \%$ of the households were deemed creditworthy (Johnston and Morduch 2007). MFIs rarely serve very poor people at the bottom of the poverty scale. There are substantial numbers of people who are not served and there is a debate about whether microfinance is actually suitable for the really poorest. (Hashemi and Rosenberg, CGAP, 2006). Hulme and Mosley 
(1996) in their study reach a conclusion that "microloans are more beneficial to borrowers living above the poverty line than to borrowers living below the poverty line". Most MFIs prefer to target the "upper poor" than the "very poor" in order to achieve sustainability, and the very poor are thus not being served by MFIs unless their programs are intentionally designed to reach them (Hickson, 1999). Rasmussen et al. (2005) estimate that $10 \%$ of households in Bangladesh are too poor to be able to benefit from the microfinance and suggest that other services like grants and savings may be more suitable for these people.

Other reason why the extremely poor do not participate in microfinance services may be because they are worried about the consequences of not being able to repay the loan back (Hashemi and Rosenberg, CGAP, 2006). For the poorest the opportunities for productive use of loans are usually limited, because the weekly meetings are too time-consuming and risk of default is very high (Wright and Dondo, 2001). The assumption that mutual solidarity will ensure that the successful members will cover for the defaulters increases the likelihood that the poorer will be considered not sufficiently reliable and will be rejected by the group (Gobezie, 2004).

Vijay Mahajan, the chief executive of Basix, an Indian rural MFI, concludes that microfinance"seems to do more harm than good to the poorest, as those poor who cannot earn a greater return on their investment than the interest they must pay, they will become poorer as a result of microcredit, not wealthier." (Karnani, 2007).

For example, in Bangladesh, where most of the MFIs are focused on the very poor and microfinance environment is friendly, the poorest communities do not participate in microfinance programs and concentration of MFIs is highest among the second poorest quintile group and lowest among the poorest quintile (Zaman, World Bank, 2005). Based on the Nawaz study from Comilla district (2004) more than $65 \%$ of the households, mainly from the bottom layer of extremely poor households, were not reached by three main MFIs operating in the area, in particular by Grameen Bank and ASA.

Studies suggest the poorest seldom benefit from microfinance, while the middle and upper poor benefit the most and the poorest, $10-15 \%$ of the population, are largely excluded from microfinance programs. As per experience of the first author of the paper made in a variety of several Mexican MFIs during a period 2006-2012, the unreached percentage continues to grow due to stricter credit analysis criteria caused by rising overindebtedness. (Hes, 2012). Microfinance institutions' apparent "failure" to reach the poor may not be a failure at all, "but rather, a realization that microfinance is not the way out of poverty for all the poor." (Zaman, 1997). Hulme and Mosley (1996) surveyed "successful" microfinance programs in seven different countries. In all microfinance programs, the average earnings of borrowers increased, however, borrowers below the poverty line actually had lower incomes than before joining the programs. They assumed that the better-off borrowers tend to invest in riskier and more productive ventures, including technological improvements and concluded that "while credit may be an effective vehicle for boosting the incomes of the poor, it may be counter-productive, in helping the poorest of the poor raise their living standards and alternative poverty reduction mechanisms are probably advisable for this group."

According to the findings from 15 studies conducted in Sub-Saharan Africa elaborated in Policy Brief in 2010 by Stewart et al., microfinance clients were made poorer, and not richer, by microfinance. This seems to be especially because they consume more than invest in the future and their businesses fail to produce enough profit to pay high interest rates. The emphasis on reaching the poorest of the poor thus may be flawed and microsavings may be a better tool to alleviate poverty than microcredit. Pollin (2007) puts this view in the following 
words: "Micro enterprises run by poor people cannot be broadly successful simply because they have increased opportunities to borrow money. For large numbers of microenterprises to be successful, they also need infrastructure and marketing support to reach customers".

Savings services for the poorest follow similar path as loan services. Behavioral explanations for the difficulty of saving focus on those who wish to but prove unable to save. (Atkinson et a., 2012) Self-control problems arise for reasons such as hyperbolic discounting (Laibson, 1997), intra-household disagreements (Ashraf et al., 2010), temptation goods (Banerjee and Mullainathan, 2009), or procrastination (O'Donoghue and Rabin, 2001). The issue of forced savings mobilisation may increase poverty and observations show that forced savings mobilisation, although meant to instigate a culture of saving discipline, does not match the realities of socio-economic situation of the poorest of the poor (Pitamber, 2003).

On the other hand program developed by BRAC in Bangladesh has reached in the past 5 years 300,000 extremely poor households and suceeded to lift $75 \%$ of these over food security level and into management of sustainable economic activities, thus lifting them into microfinance target market (CGAP, 2012). The strategy is being replicated by the CGAPFord Foundation Graduation Program and is likely to change the negative paradigm on link betweeen extreme poverty and microfinance.

Drawing the line between the undernourished people who cannot even resolve basic nutrition needs and extreme poverty, 243 million adults in developing countries who are severely undernourished, judged by a body mass index of less than $17 \mathrm{~kg} / \mathrm{m} 2$, can be considered too poor and disqualified from microfinance market (Kent, FAO, 2002). The potential market of 2.5 billion unbanked adults as per latest Financial Accesss initiative estimate is thus naturally reduced by 243 million of Antimarket type A non-clients.

\section{2. Market not interested in microfinance}

Not all potential savers are interested in savings, being currently the most important service in microfinance sector, as per number of clients. These uninterested clients should not be included into realistically taylored microfinance market estimates. We logically assume that relative part of population in developing countries will not surpass the level of saving population in high income economies in foreseeable future, due to a variety of factors, financial literacy being the key one. Currently only 45 percent of adults in high-income economies report having saved at a bank, credit union, or microfinance institution in the past 12 months (World Bank, 2012).

A large part of the maginalized populations that can earn a financial income may signal a latent demand for financial services in general, but not for microcredit. (DB Research, 2012) Many poor simply are not want active as enterpreneurs and wide part of the poplation would prefer to be employed than to take up risks of enterpreneurship. And those, who already run a business, can be reluctant to enter into debtorship status by taking on creditors capital. Thus, the latent demand for microcredit seems to be limited and the actual gap in serving the poor is much smaller than the estimates (DB Research, 2012).

Many poor clients don't have a use for microloans, even if they qualify for them, are reluctant to accept a repayment schedule or finance their investments through other informal means, lacking the skills, vision, creativity, and persistence to be entrepreneurial. As cited in Chanana (2007), "even in developed countries with high levels of education and access to financial services, about $90 \%$ of the labor force is employees, not entrepreneurs". 
In 2002, microlending officers from Bank Rakyat Indonesia interviewed 1.438 households chosen at random in 72 villages throughout six provinces, and less than $25 \%$ had borrowed from any formal microlender in the past 3.5 years, despite proximity to such a provider (Johnston and Morduch, 2007). A survey of 17,000 microenterprises in Ecuador found that only about a half did apply for credit because they either did not want to be indebted (37\%) or did not need a loan (14\%), in spite of major expansion in microfinance loans in the country (Magill and Meyer 2005). One of the more interesting findings of the study was that $50 \%$ of those who had not applied for a loan during the past years did not want loans under any terms. Navajas and Tejerina (2006) reviewed surveys of microbusinesses in Ecuador, Guatemala, Nicaragua, Panama, and the Dominican Republic, and concluded that only $20 \%$ of people had applied for a loan. Karlan's research reported the share of people who accepted the loan offer between 5 and $15 \%$ in Peru, Mexico, Ghana, Morocco, the Philippines, and India (Anand and Rosenberg, 2008).

Reports of total market penetration in Bangladesh paint a different picture. Between 2003 and 2004, MFIs and government microfinance programs in Bangladesh reported 23.8 million members, but only two-thirds were active borrowers. In the "Big Four" MFIs Grameen, BRAC, ASA, and Proshika, $80 \%$ of their clients had an active loan. In the other NGOs surveyed, around $65 \%$ of the members had an active loan (Rasmussen et al., 2005). These numbers suggest that a significant reduction should be made of the expectations related to volume as well as numbers of available clients.

The 2006 World Bank study estimated that microfinance reached $62 \%$ of poor families in Bangladesh, with a mature microfinance market, while in countries like Bolivia and Indonesia fall far below the penetration levels reported in Bangladesh, despite difficult comparability of the mentioned markets. On balance, most microfinance demand estimates are probably overstated, sometimes by wide margins (Anand and Rosenberg, 2008).

CGAP assumes that most current demand estimates expect that at least half of the target population would be borrowing at any given time if microcredit were available in their areas (Ibid, 2010). Based on the numbers stated in the available studies, we thus consider that at least $50 \%$ of the most optimistic potential target population, which is derived from the number of unbanked adults estimated by FAI at 2,500 million comes to 1,250 million adults in developing countries, would be not interested in a microloan, adding next 625 million nonclients to Antimarket type A and B. As to savings, when we apply the benchmark of high income countries, with only $45 \%$ of people saving on periodic basis in developed world, the realistic market estimate of those not targetable as interested savings clients. is similar to previous estimate, 1.125 million of people.

\section{3. Sick clientele}

An important part of the population in developing countries is unacceptable as microfinance clientele, due to incapacity to service debts or related high risks. Into major categories for such types of clientele can be considered ill, disabled and mentally ill.

The three most devastating diseases: HIV/AIDS, tuberculosis, and malaria together, these "Big Three" account for the loss or incapacity of 76.864 million ${ }^{1}$ potential clients (Hotez et al., 2006). As stated by (Roenne and Wagner, GIZ, 2005) targeting HIV positive clientele threatens not only the financial sustainability of MFIs, as the ability of affected

${ }^{1}$ Number calculated by authors based on data from (Aids.org, 2000), (Avert, 2010), (Gatesfoundantion, 2009), (WHO, 2012), (WHO, 2010a) and (WHO, 2010b). 
families to pay back their arrears diminishes and the proportion of productive clients declines, but may even further harm the household's economic position. Provision of microfinance in areas where illness such as HIV/AIDS pervades can be troubled by such developments as entire loan groups dying, loans going into default, or borrowers being forced to use compulsory savings for health expenses (Caldas et al., 2010). Most practitioners thus agree that the most important role of MFIs is to continue to serve only those who can make use of financial resources (Parker et al. 2010).

Although few successful examples of microfinance programs for PLWHA were described in the literature, MFIs usually recognize the special challenges of minimizing risk of loan default and do not target microfinance to a single type of high-risk client.

As an example serves the case of URWEGO, a leading microfinance bank operating in post-conflict Rwanda. URWEGO provided microfinance to poor women whose husbands had died of HIV/AIDS. Most of them were also HIV positive, and reached the symptomatic stage within a few months after joining the program. As a few borrowers fell sick, stopped attending meetings and failed to repay, the other members of the group stopped paying also and the entire scheme quickly collapsed (Parker and Pearce, CGAP, 2002).

Another example can be found in Kenya, where Women fighting AIDS in Kenya (WOFAK), an AIDS support national NGO, tried to raise and sell vegetables to secure a source of income, but discover that no one would buy their vegetables because of the stigma associated with HIV/AIDS. The explicit targeting to PLWHA has resulted in negative outcomes (Donahue, 2000).

If only considering the severely ill through three most widespread diseases, disregarding the number of victims of other illnesses or impaired ones, we arrive at number of other 76.9 million people incapable of becoming microfinance clients, belonging to Antimarket type A.

\section{4. Displaced people}

People without firm presence in their local markets are naturally excluded from microfinance dynamics, which focuses on financing of microenterpreneurs well integrated in the tissue of their local markets.

As per 2010 UNHCR Global Trends report, 43.7 million people were displaced worldwide. Of these, 15.4 million were refugees - 10.55 million under UNHCR's mandate and 4.82 million Palestinian refugees registered with UNRWA. Within this total were also 27.5 million internally displaced persons within their own country by conflict and 837,500 asylum-seekers.

\section{5. Culture and religious reasons}

$44 \%$ of world's microfinance clients currently live in Muslim majority countries claimed CGAP in 2011. The Shariah-compliant micro loans, acceptable for the mentioned populations, albeit expanding rapidly make up less than 1 per cent of the industry typically use the murabahah concept, in which the financing party purchases assets for the client and sells them at a predetermined profit margin (Khan, 2011; Permatasari, 2010). The conventional microfinance scheme is however unacceptable in shariah-compliant market due to $\mathrm{riba}^{2}$ on loans, due to riba on savings as well as maysir ${ }^{3}$ on insurance, basically forbidding

\footnotetext{
${ }^{2}$ Concept of interest prohibition in Islam

${ }^{3}$ Concept of gambling or speculation prohibited by Islamic Law.
} 
these concepts, rendering microfinance an incompatible financial mechanism with Shariahcompliant finance.

Despite size of market, the demand can be met only if low income clients are convinced about the authentic Islamic nature of the product which is not the case at present (CGAP, 2008). The currently used Murabaha concept harbours several legal as well as religious obstacles which render the Islamic market limited, despite attempts of religious leaders, scholars and practitioners to find way forward.

Surveys conducted in Jordan, Algeria, and Syria revealed that between $20-40 \%$ of respondents consider religious reasons as the main obstacle for obtaining conventional microfinance (Karim et. al, CGAP, 2008). Particularly, in Jordan $32 \%$, in Algeria $20.7 \%$ and in Syria $43 \%$ of the potential clients surveyed cited religious reasons for not accessing microfinance.

In addition, $46 \%$ of Syrian respondents who had never applied for a loan stated that religious reasons were the primary reason they had never applied and about $5 \%$ of current borrowers who had already applied said they would not apply for a loan for religious reasons (IFC, 2007). Not only those who do not use microfinancial services, but also active clients are influenced by cultural and religious bias. Such influence came out of a field study carried out in Ankara by team of students of Czech University of Life Sciences in 2012, evidencing that $8.5 \%$ of the microcredit holders are pressurized by their religious to leaders to quit the use of conventional microfinance.

If we consider populations living under Sharia Islamic Law ${ }^{4}$, which practically bans the conventional microfinance due to existence of interest, whether in form of loan, deposit, or fixed return for the investor, we come to the number of 155.5 million adults ${ }^{5}$ that may not be integrated within the present microfinance market expectations.

\section{6. Totalitarian regimes and conflict ridden regions}

The environment has a significant effect upon the establishment and succesfull execution of microfinance services and security is the most important factor for sustainable MFIs. Post-conflict environment is not compatible with the normal context for successful microfinance operations, as one of the pre-conditions for microfinance include the absence of violent conflict, and a reasonably "rooted" population (FindArticles, 2009).

Also generous relief grants, provided in post-crisis areas can have a negative effects on microfinance during decades of peace, as the relief interventions can damage future of development. If we consider totalitarian states such as Cuba and North Korea, and add Somalia, top country listed on failed states index ${ }^{6}$ and consider their adult population as unfit for conventional microfinance operations due to extreme insecurity or simply microfinance operations forbidden by the state, we arrive to the conservative conclusion that 30.1 million $^{7}$ people should not belong to the global market estimates.

\footnotetext{
${ }^{4}$ Iran, Libya, Nigeria, Oman, Saudi Arabia, Sudan and Yemen.

${ }^{5}$ Number calculated by authors based on data from (CIA, 2012).

${ }^{6}$ Number calculated by authors based on data from (CIA, 2012).

${ }^{7}$ Number calculated by authors based on data from (CIA, 2012).
} 


\section{SUMMARIZING ESTIMATE OF THE UNATTENDED GLOBAL MICROFINANCE SECTOR}

The following estimate of the unattainable global microfinance sector is derived from the obvious segments of the clientele, that cannot be served and should not be included in the current simplistic assumptions of the total market potential.

Our estimate is imperfect due to potential overlapping of characteristics of mentioned groups as well as because of incongruency between microfinance and microcredit concepts, but this issue can be offset by many other parameters that were not included in the study, such as role of sex within the context of microfinance products focused predominantly on women.

Also, if we consider other additional, not quantified factors such as social exclusion and discrimination of people with impairments and their families, regulatory incursions of states that can delete potentials of local markets or natural hazards, which in some regions eliminate feasibility of microfinance as a sustainable sector in the long term, we arrive to the outcome that our estimate is acceptable and conservative. After summing up groups of clients that should not be included within the total market assumptions as per Table 1 and detracting from the latest FAI estimate of population without any access to financial services, we come to the conclusion that there is at least 524,5 million people wrongly assumed to be part of total microfinance demand.

The real potential market is thus reduced to 975.4 million of unattended and valid client for sustainable microfinance.

Table 1. Total reduced microfinance market.

\begin{tabular}{|c|c|}
\hline Antimarket $A_{\text {Unqualifiable clients }}$ & $=243$ million \\
\hline Antimarket $A_{\text {Disease }}$ & $=76.9$ million \\
\hline Antimarket $\mathrm{B}_{\text {Displaced }}$ & $=43.7$ million \\
\hline Antimarket $\mathrm{B}_{\text {Religion }}$ & $=155.5$ million \\
\hline Antimarket $\mathrm{B}_{\text {Totalitarian }}$ & $=30.1$ million \\
\hline Antimarket Total ANI & $=549.2$ million \\
\hline Market $_{w / o}$ access to finance FAI estimate & $=2500$ million \\
\hline Market corrected full estimate (FAI est. -Antimarket) & $=1950,8$ million \\
\hline Antimarket $\mathrm{A}_{\mathrm{Not}}$ interested clients & $=975,4$ million \\
\hline Market ${ }_{\text {Total realistic estimate }}$ & $=975,4$ million \\
\hline
\end{tabular}




\section{IMPLICATIONS OF DISTORTED VISION OF MICROFINANCE MARKET POTENTIAL}

Exaggerated notion of vastness of available markets as well as extent of unattended human needs is a cause for synergetic variety of detrimental processes. It fuels proliferation of capital, which does not aim at proper targets of microfinance as a tool of fight against poverty, as it mistakenly views in microfinance a panacea for more that it can accomplish, leading to superficial placement.

Another problem is an oversupply of uncritically conceded capital funding induced by sources driven by pressures of aroused public opinion, luring MFIs into rapid growth, which either exceeds the debt burden the clients can manage or destabilizes the market due to incapacity of the institutional debtors to manage the capital and going bankrupt. As no international black list, nor reliable data on MFI bankruptcies and loan defaults is disponible, despite periodically ocurring mishappenings, successful MFIs receive a lot of attention, while there is no public analysis of bankruptcies, hypocritically treated as a non-existing and shun away from the spot light.

Although defended with a development rhetoric, great part of support for microfinance seems to be based on simple but superficial poverty relief; it gets some resources to the poor (Practical Action, 2012).

Noxious long term implication of the overstatement is a gradual cementation of a myth of microfinance as a mainstream sustainable development product, suited for any conditions in any project due to bankability of most people, instead of building up the vision of microfinance as a niche instrument which needs to be operated with care, prudence and understanding of local complexities.

\section{CONCLUSION}

The estimates of total microfinance demand are based upon simplistic assumptions putting equal sign between the number of unbanked adults living in developing regions and estimated microfinance clientele, disregarding whole variety of factors in the expectation that most qualifying people in productive age can be considered clients. Once considered and taken into account limitations of the market, these clearly reduce the global potential of microfinance to a fraction of widely used numbers. Eventhough some approximation is needed due to imppsibility of an exact estimate, according to the authors, the numbers involved in literature are widely misguiding.

The study defined several areas, where the inclusion of clientele as a microfinance target market can be considered a misguidance. As such could be included portion of clientele that cannot qualify for a loan, ill and sick clientele, displaced ones, culturally inapt populations to take up loans or people living in totalitarian regimes of conflict ridden regions. Unqualifiable clients who are found in any market disregarding its geographic location sum up at least 320 millions and clients of type B, living in specific regions exceed 229 millions.

When these numbers are added the sum of qualified clients who are expected simply not to be interested in microfinance, independently on their capacity to become such which varies around half of billion people out of the total of the estimated market, the study arrives to a gross number of almost half a billion wrongly assumed to be part of a potential microfinance market. This detection of deep diference contrasting with common estimates leads us to an 
alerting finding that numbers used in common reasonings related to microfinance potential are exaggerated and should be thus discarded as mainstream development propaganda, uncritically using shallow information not founded on realistic assumptions nor subjected to consequent considerations.

Despite the limitation of this paper due to no distinction between sustainable MFIs and non-profit MFIs driven by social goals, where sustainability is not key target, the use of basic logics leads us to propose diminution of the global view of this market as a more undersized space for development and for microfinance impact, when compared to the common expectations. Microfinance, as a tool of development, seen in this light of critical view, not open or advisable for a major part of human population due to to multiple requirements of different nature related to peculiarities of handling with finance, stays an important instrument in the fight against poverty, however on a more limited scale than so often cited or proclaimed by development practitioners.

\section{List of abbreviations}

FAI Financial Access Initiative

MFI Microfinance Institution

MIV Microfinance Investment Vehicle

NGO Non-governmental organization

PLWHA People Living With HIV/AIDS

\section{References}

[1] Aids.org., How many people have HIV and AIDS?, 2000, http://www.aids.org/topics/aids-faqs/how-many-have-hiv-aids/, accessed 1 April 2012.

[2] Allden S., Microfinance and post-conflict development in Cambodia and Timor-Leste, 2009, FindArticels, http://findarticles.com/p/articles/mi_hb3413/is_2_24/ai_n45060694/, accessed 1 April 2012.

[3] Anand M., Rosenberg R., Are We Overestimating Demand for Microloans? CGAP, Washington: World Bank 2008.

[4] Bernhardt A., The Microfinance Market Today, GC Capitalideas, 2009, http://www.gccapitalideas.com/2009/06/10/the-microfinance-market-today/, accessed 1 April 2012.

[5] Brugger E. A., Duggal B., Micro-finance Investment Funds: Looking Ahead. Zurich: KfW, 2004.

[6] Caldas A., Arteaga F., Muñoz M., Zeladita J. et al., Journal of Health Care for the Poor and Underserved 21(3) (2010) 986-1005.

[7] Connecticut. In: Morduch J., Haley B., Analysis of the Effects of Microfinance on Poverty Reduction. New York: NYU Wagner, 2002.

[8] Chaia A. et. al., Half the World is Unbanked, Financial Access Initiative, 2010.

[9] Donahue J., HIV/AIDS and Economic Strengthening via Microfinance. Washington: U.S. Agency for International Development, 2000. 
[10] Gobezie G., Microfinance Development: Impact on Poverty and Food In-Security be Improved Upon? International Conference on Microfinance Development in Ethiopia, 2004.

[11] Hashemi S., Rosenberg R., Graduating the Poorest into Microfinance: Linking Safety and Financial Service. CGAP, Washington: World Bank, 2006.

[12] Hickson R., Reaching Extreme Poverty: Financial Services for the Very Poor. Office of Development Studies:United Nations Development Programme, 1999.

[13] Hotez P. J., Molyneux D. H., Fenwick A., Ottesen E., Ehrlich Sachs S., et al., PLoS Med 3(5) (2006) 102.

[14] Hulme D., Mosley P. (1996), Finance Against Poverty. London: Routledge. In: Karnani A., (2007) Microfinance Misses Its Mark. Stanford Social Innovation Review.

[15] IFC, (2007), Syria Microfinance Market Assessment, Draft Report. Washington: IFC/The World Bank. In: Karim N., Tarazi M., Reille X. (2008), Islamic Microfinance: An Emerging Market Niche. CGAP, Washington: World Bank.

[16] Johnston Jr. D., Morduch J., The Unbanked: Evidence from Indonesia. New York 2007.

[17] Karim N., Tarazi M., Reille X., Islamic Microfinance: An Emerging Market Niche. CGAP, Washington: World Bank 2008.

[18] Kendall J., Mylenko N., Ponce A., Measuring Financial Access around the World, Washington: World Bank 2010.

[19] Kent G., The Human Right to Adequet Food. FAO, Honolulu: Department of Political Science University of Hawaii 2002.

[20] Lyman T., Lythgoe T., Miller M., Reille X., Sankaranarayan S., Credit Reporting at the Base of the Pyramid: Key Issues and Success Factors. Washington: CGAP and IFC, 2011.

[21] Magill J. H., Meyer R. L. (2005), Micrenterprise and Microfinance in Ecuador. Washington: USAID. In: Anand, M. and Rosenberg, R. (2008) Are We Overestimating Demand for Microloans? CGAP, Washington: World Bank.

[22] Morduch J., Haley B., Analysis of the Effects of Microfinance on Poverty Reduction. New York: NYU Wagner 2002.

[23] Navajas S., Tejerina L. (2006), Microfinance in Latin American and the Caribbean: How Big Is the Market? Washington:Inter-American Development Bank. In: Anand M., Rosenberg R. (2008), Are We Overestimating Demand for Microloans? CGAP, Washington:World Bank.

[24] Nawaz S. (2004), An evaluation of micro-credit as a strategy to re-duce poverty: A case study of three micro-credit programs in Bangladesh. In: Islam M. R., Sharmin K. (2011), Social Exclusion in Non-government Organizations (NGOs) Development Activities in Bangladesh. Sociology Mind, 1(2): 36-44.

[25] Parker J., Pearce D.Microfinance, Grants, and Non-financial Responses to Poverty Reduction: Where does Microcredit Fit? CGAP, Washington: World Bank 2002. 
[26] Parker J., Singh I., Hattel K., (2010) The Role of Microfinance in the Fight against HIV/AIDS. UNAIDS Background Paper. Maryland: Development Alternatives, Inc. (DAI), 2010.

[27] Pollin R., Microcredit: False Hopes and Real Possibilities. Washington: Foreign Policy In Focus, 2007.

[28] Pollinger J. J., Outhwaite J., Cordero-Guzmán H., Journal of Small Business Management 45(1) (2007) 23-41.

[29] Swanson B., The Role of International Capital Markets in Microfinance. Washington:Developing World Markets, 2007.

[30] Swibel M. (2008) Microfinance Fever. Forbes 2008, http://www.forbes.com/forbes/2008/0107/050.html\%202008, accessed 1 April 2012.

[31] Trant J., Microfinance: Investing with an Impact. NewYork: International Association of Microfinance Investors, 2010.

[32] van Maanen G., Microcredit: Sound Business or Development Instrument? Voorburg: Oikocredit, 2004.

[33] Versluysen E., Defying the Odds: Banking for the Poor. Kumarian Press, 1999.

[34] World Bank. (2006) Microfinance in South Asia: Toward Financial Inclusion for the Poor. Washington:World Bank. In: Anand, M. and Rosenberg, R. (2008) Are We Overestimating Demand for Microloans? CGAP, Washington: World Bank.

[35] Wright G. A. N., Dondo A., Are You Poor Enough?: Client Selection by Microfinance Institutions. Nairobi: Microsave, 2001.

[36] Zaman H., Development in Practice 7(1) (1997) 82-89.

In: MacIsaac, N. (1997) The Role of Microcredit in Poverty Reduction and Promoting Gender Equity A Discussion Paper. Strategic Policy and Planning Division: Asia Branch Canadian International Development Agency (CIDA).

[37] Zaman H. (2005), The Economics and Governance of Non Government Organizations (NGOs) in Bangladesh. Washington: World Bank In: Hashemi, S., Rosenberg R. (2006), Graduating the Poorest into Microfinance: Linking Safety and Financial Service. CGAP, Washington: World Bank. 